\title{
Research support through the lens of transformation in academic libraries with reference to the case of Stellenbosch University Libraries
}

\author{
Reggie Raju ${ }^{1}$ and Lucia Schoombee ${ }^{2}$ \\ reggie.raju@uct.ac.za, Ics1@sun.ac.za
}

\begin{abstract}
Received: 30 November 2013
Accepted: 15 January 2014
\end{abstract}

\begin{abstract}
Changing higher education pedagogy, digitisation of scholarly content and the increasing influence of relevant technologies have impacted on the transformation of academic library services. This paper examines research support through the lens of the transformation of academic library services. The authors have conducted a review of the literature to determine benchmarks by which to measure the research support services delivered by Stellenbosch University. The paper examines academic libraries' attempts to establish the "deeper meaning" of the librarian for the researcher and the research process. In support of that deeper meaning libraries are providing a new and expanded set of services which includes, inter alia, research data management, curation and preservation; facilitation of open access and bibliometric analysis. Using the research life cycle as a framework, this paper examines the research support services provided by the Stellenbosch University Library and Information Service (SULIS) to the research community. The Research Commons is used as the launch pad for new and innovative services at Stellenbosch. The use of research performance management tools to scan the research landscape, strengthening of self-retrieval of scholarly literature, assistance in the dissemination of research results via publication, and assistance in determining impact factor are all part of the suite of services offered by the Library at Stellenbosch University. The authors conclude that, for academic libraries, there is much to learn and contribute to in this dynamic environment of research production.
\end{abstract}

Keywords: Academic libraries, bibliometrics, research librarian, research support, research support librarianship, research data management, data curation

\section{Introduction}

It is beyond debate that academic libraries are in transition influenced by a myriad of factors. Many subscribe to the view that the transition is influenced by the desperate need to regain relevance. Gayton (2008: 60), for example, proclaims that "the impending death of the traditional library" has resulted in libraries creating new spaces and implementing new services: these new spaces and services are adopted to stave off any continuance of being on "life support". Anderson (2011: 289) adds to this sense of desperation when he comments that academic libraries will become irrelevant if they continue on the path of service provisions based on "an eroding traditional functional model". However, the authors of this paper are more optimistic and prefer the stance that libraries are in transformation due to their positive and proactive response to the demands of changing higher education pedagogy and e-science.

The authors draw their optimism from decisions taken at the UNESCO conference on higher education which was held in Paris in 2009 (UNESCO 2009). It was at this conference that leading academic institutions committed to realigning their foci within their core functions of research, teaching and service to the community, to incorporate the promotion of critical thinking. The principle of developing and nurturing critical thinking in higher education strengthens the paradigm shift in pedagogy: a shift from education being a domesticator to education being a liberator. That is, the changing role of the lecturer as a top-down deliverer of education (domestication) to the lecturer as a facilitator in the education process (education as liberator). Corroborating this shift in pedagogy is the comment by Bennett (2008: 183) that education is moving away from teaching to learning. Therefore, it is imperative that libraries focus on the process of learning that takes place within its spaces, bringing resources, learners and experts into easy proximity to facilitate collaborative learning (Thachill 2008).

Within this new higher education paradigm, where education is mooted to be done collaboratively, libraries are purported to be at the core. Libraries have always been quick to adopt relevant technologies to ensure efficient and effective support for the education process. The proactive response of the library to the demands of changing higher education pedagogy has stimulated new thinking with regard to innovative learning spaces and aligned new services. Some of these new services include virtual reference services, collecting and digitising archival materials, creating supportive metadata and maintaining digital repositories.

Given that higher education libraries, as a whole, are in transformation, this paper will focus on one area of growth and development, namely, support for research and researchers. As a point of clarification, the authors accept the

1. Reggie Raju (PhD), who is the corresponding author, is the former Director: Client Services, Library and Information Service, Stellenbosch University. He is currently the Deputy Director: Client Liaison Services, UCT Libraries, University of Cape Town.

2. Lucia Schoombee is the Senior Librarian: Research Support, Library and Information Service, Stellenbosch University. 
cautionary comment of Parker (2012) that research support is much more than the provision of reference services for "students to complete their homework assignments". Research support is the provision of a new and expanded suite of services such as research data management, curation and preservation, facilitation of open access and bibliometric analysis. Therefore, it is important that the authors define the concept "research support" before teasing out new roles and responsibilities associated with these new services.

It is accepted that research support librarianship, in this new and contemporary format, is a relatively new area of service provision by higher education libraries (especially in the South African context). The authors are therefore of the opinion that this paper will be of interest to the higher education library sector as a whole. Further, the discussions in this paper could be used as a building block for the growth and development of a new model of service provision by higher education libraries.

\section{Methodology}

Denscombe (2012: 55) makes the point that the use of more than one research method sits comfortably with the case study approach. The case study approach works best when researchers investigate an issue in-depth and provide an explanation for the issue. Given that research support librarianship is relatively new and very much in its fledgling stage in developing countries, it was important for the authors to conduct a thorough review of the literature to establish new trends and new roles and responsibilities of the new research support librarian. It is against this review of the literature that the authors examined current research support librarianship trends in South Africa, making specific reference to the implementation of research support services to the research community at Stellenbosch University. This method is supported by Fouché and Delport (2012: 134) and Leedy and Ormrod (2013: 141) who make the assertion that a conceptual framework for the study needs to be established to indicate where the study fits into the broader debates. More importantly, "the literature is used to sharpen the focus of the study" (Fouché and Delport 2012: 135).

The case study approach using Stellenbosch University conforms to the views of Gorman and Clayton (2005: 47) who define a case study as an investigation of an "entity on the assumption that it is possible to derive knowledge of the wider phenomenon from intensive investigation of a specific instance or case". The combination of a review of the literature and the case study of Stellenbosch University provided the researchers with sufficient evidence to draw conclusions and make recommendations on this emerging area of research support librarianship in the higher education library sector.

\section{Academic libraries in a new paradigm}

Kwanya, Stilwell and Underwood (2012:1) quote the Special Libraries Association which states that the basic professional tenets of librarianship remain the same while the methods, tools, scope and environment of information delivery continue to change dramatically. Academic libraries have become increasingly more dynamic entities. The dynamism of the academic library, in the second decade of the 21st century, is illustrated by the continuous adoption of new philosophies to ensure relevance, effectiveness and efficiency. The library has moved from the "pull philosophy", that is, drawing the users into the physical entity and rendering a service to those that are in the library to the "push philosophy", that is, taking the library to the users. The conversion of print content into digital format and the ubiquitous nature of digital information have served as the impetus to push the boundaries in terms of taking the library to the users. In this age of a surfeit of information libraries are working towards and consolidating an "in your space" philosophy, that is, having a virtual presence in the space of the researcher. To be in the space of the researcher, the library must ensure that the user has access to full-text from the widest range of mobile devices (Stoffle, Leeder and Sykes-Casavant 2008; Basefsky 2009; Sennyey, Ross and Mills 2009).

Staley and Malenfant (2010: 65) add another dimension to the transformation of academic libraries making specific reference to research support. They point out that

libraries will need to reconsider what their relevance is in the research process. We need to start considering what our "deeper meaning" is to researchers to ensure that we fit into this new model. We feel strongly that we will have a role - it will look different from our role now, and we need to be careful not to cling to past practice for nostalgic reasons.

Amidst this transformation through the philosophies mentioned above and their concomitant practises, is the growth of new facilities and services to the research community.

The provision of new facilities and services to researchers must be viewed within the context of the change in the research information landscape which is now characterised by ubiquitous, digitised and online access to content. Therefore, it is imperative that libraries play a more significant role in the creation of research information and in connecting research communities. Walker (2009) suggests that some of the new services that academic libraries should be providing in this new research landscape include management of institutional repositories, management of vast research data sets and provision of specialised information technology services.

\section{Research librarian defined}

It is against this background of the transformation in the academic library landscape, the ubiquitous nature of information and the deluge of information, that the authors examine the concept of research support librarianship. 
As indicated earlier, Parker (2012) opines that "research support" is more than the traditional provision of services to assist students and others who are conducting research. She provides a simple but definitive description of the concept of "research support" as a set of services and facilities which assist in increasing research productivity and scholarship. Raju and Schoombee (2013) add that research support is the proactive engagement of the librarian with the researcher. The research librarian is an active partner in the research production process, from the initial stages of engagement with the researcher in the research process to the eventual publication of the thesis or dissertation or research article. Somewhere in the continuum from the initial stage to the publication stage are traditional services using appropriate technology. The research librarian is an important cog in the research production cycle bringing skills and experiences to the process that will benefit the researcher and the research product. Hence the shift in the role of the librarian is from a supporter of the research process to a contributor to the process.

\section{Research support trends}

A review of the literature reveals two significant trends in research support, namely, the repurposing of library spaces and the provision of new services. Further, this review has revealed that in the changing role of the library, the library provides new facilities and services that enhance its capacity in its transition from a supporter of the research process to a contributor to the process. The provision of new spaces, the Research Commons being an exemplar, and the provision of new services are not mutually exclusive. The synergy between the new physical spaces and the new services serves to elevate the library's contribution to the research process.

\subsection{Repurposing of library spaces}

Academic libraries are repurposing spaces to align their facilities for improved contribution to collaborative learning providing support for "education as a liberator". Pennington (2012) makes the point that the idea of creating a "third space" in a library environment is relatively new in librarianship. Pennington (2012) goes on to quote Oldenburg who calls the "first place" the home and the "second place" the workplace. The "third place" serves as an anchor "for community life and facilitate[s] and foster[s] broader, more creative interaction [for research and learning]... it has a valuable atmosphere that encourages collaboration for student success".

Stoffle and Cuillier (2011: 146), in discussing the library as place, make the assertion that there needs to be a reexamination and a refocusing - the focus should be on the library as a service. Library as service focuses on the customer with the underpinning principle of "everywhere-you-are access". This principle pushes the library into the research and learning environments - to the desktops, to the laboratories, and to the classroom (the authors of this paper refer to this as the "in your space" philosophy). Stoffle and Cuillier (2011: 146) go on to say that the

library as service penetrates deeply into the activities and programmes of the campus, becoming an essential partner in achieving campus strategic goals in all arenas. Library as service tries to anticipate needs before there are demands. It empowers and enables customers to be effective information users and creators.

The authors, however, are of the view that it is not a case of either/or (that is, the "third place" or the "library as a service"), as the library needs to provide spaces that support collaborative learning. This collaborative learning will be enriched with the provision of a relevant set of services.

Surprenant and Perry (2002) corroborate the views of Pennington (2012) and Stoffle and Cuillier (2011) when they affirm that in a new higher education landscape, "the library must now assume the role of being a highly interactive, proactive, digitally based, cyber mix of staff, activities and services. This role is typical of what will be offered in a Research Commons". There is support for the views of Surprenant and Perry (2002) when Stoffle, Leeder and SykesCasavant (2008), Sennyey, Ross and Mills (2009) and Basefsky (2009) all point out that the challenge within this new pedagogy is not to create digital libraries, but to envision integrated learning environments which are designed for the learning styles of a digital generation. The emphasis is on libraries providing study spaces that enable students to conduct the near-synchronous acts of information access, reading, evaluation and writing. Further, the enduring value of the library as a cultural meeting place is taking on a more extroverted character as libraries realise how potent that social element can be in fostering learning.

\subsection{New research support services}

The provision of new services must take cognisance of the fact that the currency for learning and research is shifting, and rather rapidly too, from information to data. The role of the library has always been that of distributor of scholarly information but that is changing rapidly - the second decade of the $21^{\text {st }}$ century demands from the library an expanded role in the research process through the provision of a new suite of services from the library. These new services include the collection, organisation and dissemination of research data. In this new service paradigm, the role of libraries, as purported by Borgman (2010: 13), is evolving from a "focus on reader services to a focus on author services". MacColl and Jubb (2011: 5) corroborate this shift when they add that the "channels and forms of publication have become more diverse, and many materials are published on the Web either instead of, or as well as, in their more traditional form as processed by publishers". Libraries are playing a significant role in this new "distribution (or dissemination) of information" model. Geraghty (2009) aptly describes this shift: "Think of the library inside out, what's on the fringe is now at the centre, 
and what's at the centre is now at the edge". In this new distribution of information model (or in these roles that used to be at the fringes), the library collects, organises and makes accessible the research output of the parent institution.

\subsection{Open access practices}

There are two fundamental reasons for the adoption of open access practises. The first is to address the issue of the exorbitant cost of subscriptions and the second, which is one of the foci of discussion in this paper, is capacity to improve visibility and equitable access to research output and its associated impact on society and contribution to further research. The latter is supported by Jisc (2013) which maintains that:

- Universities must increase the visibility of their research to demonstrate the contribution they make to the knowledge economy, improve their chances in the competition for government research funding and position themselves well to work with industry or third sector partners.

- An open access repository or journal is a way for authors to make their research papers freely available online. Studies have shown that such papers are more frequently cited than those solely available via subscription-based journals.

- Open access benefits not only researchers and their institutions, but the economy and society at large, as the outputs of publicly-funded research are available for all to use.

Reinforcing the need for the adoption of open access practices is the view expressed by Lee-Hwa, Abrizah and Noorhidawati (2012) that open access to research makes researchers more productive and research more effective. Further, they make the assertion that institutional "repositories have become a common platform for the academic institutions to store, share, disseminate and preserve knowledge".

Institutional repositories, as pointed out by Parker (2012), showcase a university's research output and provide equitable access to scholarly literature. She also claims that in many cases,

the institutional repository is an exemplar of a (usually library-based) research support service. It suits the needs of both researchers - in providing a single place to manage all of their publications - and the university, as a comprehensive record of its research output.

At Swinburne University, repository managers have taken on the responsibility of submitting the output on behalf of the researchers. This new service has been highly successful (Parker 2012).

To assist researchers with disseminating the results of their research through scholarly channels, libraries are increasingly offering the research community a publishing service. This gold route publishing service (institutional repositories are the green route) is becoming infectious. Park and Shim (2011: 82) point out that several libraries have recently launched library publishing services to support scholarly communication dissemination. Some of the libraries that have implemented publishing services include Columbia University Library, Cornell University Library, Duke University Library, MIT Library, and University of Calgary Library. Parker (2012) points out that Swinburne University Library publishes three journals edited by Swinburne researchers or with strong Swinburne involvement. The Swinburne library model offers its research community the following publishing services (Parker 2012):

- technical infrastructure using the Open Journals Software;

- assistance with search engine optimisation to increase the discoverability of publications;

- help with copyright and open access policies, and author guidelines;

- a DOI minting service;

- allocation of ISSNs, and ISBNs for one-off monograph editions;

- subscriptions management where necessary;

- advice on entry into abstracting and indexing services; and

- support for engagement with the ERA process to increase the visibility and prestige of Swinburne journals.

A second tier of support for publishing in open access journals is through the creation of a fund to pay author page fees. Park and Shim (2011: 82) report that Cornell University Library organised a task force on open access publishing through which institutions pay a publication fee for their faculty who publish in refereed open access journals. Similarly, MIT Libraries have developed an open access business model that helps authors publish in open access journals by utilising the MIT Open Access Article Publication Subvention Fund (OAAPSF). The University of Michigan Library has also maintained a similar publishing service through its Scholarly Publishing Office. Richardson et al. (2012) bring to the fore the Queensland University of Technology Library model. As an institutional member of selected open access publishers, the library provides financial support to researchers whose papers have been accepted for publication in selected gold open access journals.

In the current open access environment, as indicated by Riera-Quintero, Padrós-Cuxart, and Zuñiga-Ruiz (2012), research librarians guide users not only on traditional publishing practises, but also on open access publishing and the different types of usage licences for their publications (the issue of licences will not be discussed here as it is outside the scope of this paper). There is sufficient evidence emanating from the literature that demonstrates that research support 
librarians are actively providing advisory services on the different channels for publishing and dissemination of research results.

\subsection{Bibliometrics}

As discussed above, one of the primary reasons for adopting open access principles is to improve the visibility of research output. A significant spin-off of open access is that it influences the h-index of the author (measuring author impact) and the ranking of institutions. Aligned to this is the use of bibliometrics ${ }^{3}$ which, in the view of Bradbury and Weightman (2010: 67), provides evidence for assessing research quality. However, as pointed out by Roemer and Borchardt (2012: 597), there are many who have criticised the representativeness of metrics to evaluate scholarship fully. Nonetheless, "they [metrics] are still considered the gold standard" (Roemer and Borchardt 2012: 597).

As pointed out by Al, Soydal and All'r (2012: 430), bibliometrics clarifies the nature of scholarly communications and reveals trends in scientific disciplines. It provides the basis for understanding the impact of the research output and makes provision for the understanding of new trends in scholarly communication through articles and their references. The references or citations cumulatively show the most important topics that were dealt with by scholars. Astrom, Hansson and Olsson (2011) maintain that bibliometrics must be viewed against the backdrop of the significant changes to systems of research management and policy. They go on to claim that evaluation of research outcomes are increasingly linked to the allocation of research funds on various levels - from individual scholars, to institutions and national systems for academic research, such as the national level distribution of government funds between publically funded universities. At an increasing rate, bibliometric methods have been used to provide quantitative indicators for academic productivity and quality (Astrom, Hansson and Olsson 2011: 9).

Drummond and Wartho (2009: 79) maintain that bibliometric analysis has been identified as a new business area for librarians. Bibliometric services in a changing research paradigm, aided and abetted by the open access movement, are fast becoming a standard practice. There is support from Riera-Quintero, Padrós-Cuxart and Zuñiga-Ruiz (2012) and Bradbury and Weightman (2010: 68) with regard to the crucial role of the research support librarian in providing a bibliometric and research evaluation service. Corrall, Kennan, and Afzal (2013: 639) state that "many librarians have stepped forward to help negotiate the landscape of both traditional impact metrics... and emerging Web-based alternatives".

The alternative metrics to measure value of research output is in its infancy stage. Lapinski, Piwowar and Priem (2013) state that as altmetrics matures, libraries will help to facilitate an informed dialogue with the various constituencies that will intersect with altmetrics. Such constituencies include both researchers (students and faculty) and the academic administrative office (faculty affairs, research and grants, promotion committees, and such).

\subsection{Identifying research landscape service}

Riera-Quintero, Padrós-Cuxart and Zuñiga-Ruiz (2012) present a new service which has always been a forte of the librarian but never exploited to the extent envisioned in the context of new research support services. These authors point out that researchers and research groups have always used the librarian for guidance on searching for documents relevant to a user's academic or research activity. This service is now being used differently under the guise of a new research support service. This "new service" is being used at different stages of the research process, for example:

- at the research definition stage, the librarian works with the researcher to identify the field's leading authors or research groups;

- at the information search stage, here the librarian works with the researcher to establish the state of the art where existing bibliography is concerned; and

- at the dissemination stage, the librarian works with the researcher to identify journals that publish articles on a given topic. The librarian provides guidance on publishing outlets.

These stages are crafted into the research life cycle which the authors of this paper will use later to lead the discussion on research support services at Stellenbosch University.

\subsection{Research data management}

Charbonneau (2013: 365-366) makes the assertion that a direct derivative of the dramatic change in the research landscape is the exponential growth in the volume of data being generated. She goes on to draw in the significance of the library in this data deluge era recognising that data is integral to the knowledge base that underpins scholarship, provides insight into the complex world, and informs decisions about the present and the future. Within this changing paradigm, the rapid change in the nature of research demands a change in the role of libraries in supporting data-intensive research. Librarians are exploring new roles, services and types of collaborations needed to support data-centric research. A further demand for this exploration is the reorganisation, by research funding bodies, of the importance of essential infrastructure and services to organise and preserve research data. Tenopir et al. (2013: 76) maintain that academic research librarians are the most appropriately equipped to provide required research data services such as data management planning, digital curation (selection, preservation, maintenance, and archiving), and metadata creation and conversion.

3. Bibliometrics is a set of methods to quantitatively analyze patterns of publication within a given field or body of literature. 
The 2030 vision of the Association of Research Libraries (2010) and the 2050 vision of SCONUL (2011) clearly demonstrate a major shift in the use and re-use of data. In these visions, data becomes the critical product for research and the librarian must be skilled to provide the above-mentioned services. Again, these services are commensurate with what was mentioned earlier with regard to data becoming the new currency for knowledge creation and innovation.

As librarians grow their skills and expertise in data management, they can become uniquely situated to support data management processes throughout the research life cycle. However, due to constraints of space, the authors will not discuss data management services aligned to the research life cycle. Charbonneau (2013) and Lynch and Carleton (2009), amongst others, discuss the issue in depth.

\subsection{Partnerships/collaborations}

The changing research librarianship paradigm demands that the library view itself as a valuable and active partner in all aspects of the research lifecycle. In this extended service model, the library forms partnerships with key stakeholders to ensure consistent and high-quality support for research. It has been suggested by Parker (2012) that libraries enhance research support by developing customised support services and, where appropriate, embedding information specialists, with discipline-specific expertise, in departments and research centres/teams.

In this new paradigm where the librarian plays a significant role in the research production process, libraries are largely in uncharted territory and have the opportunity to draw a new road map of support and services for researchers. An exemplar to demonstrate this collaborative relationship is that of Queensland University of Technology, Australia. At this institution the library has partnered with cognate institutional services

such as Student Academic Services, supporting Student Learning Support Services postgraduate sessions, Postgraduate Student Association interactive sessions, Faculty of Graduate Research orientation sessions, and the Research Office through the research output verification and new researcher orientation sessions (Parker 2012).

This pooling of resources and skills augurs wells for an enhanced researcher experience.

\section{Case study: Stellenbosch University Library and Information Service (SULIS)}

It is against the backdrop of the above-discussed provision of new services and facilities that this paper discusses the case of research support at Stellenbosch University (SU).

\subsection{Strategy}

The strategic plan and concomitant goals of the Stellenbosch University Library and Information Service (the Library) are informed by the strategic foci of the University. Here, the authors make reference to the specific strategic focus of the University that informs the Library's strategic goals, namely, "broadening the knowledge base" (SULIS 2010). The Library responds to this strategic focus with two library-specific strategic actions, namely:

- Developing the Library as a vibrant and inviting physical and virtual space that promotes collaboration, social networking, as well as private study and reflection; and

- Supporting, developing and contributing to high-level scholarly publication output and sharing research data and results with the rest of the world, especially with researchers from the developing world via various open access initiatives. (SULIS 2010)

Both of these strategic actions of the Library contribute significantly to the implementation of new services to support research.

The above-mentioned strategy and the associated physical structure and policies are important for the Library in pursuit of its goal to advance and expand research support services, thus affirming its commitment to nurturing a strong research support environment. The Library's strategic plan, Strategic Directions 2010-2015 (SULIS 2010) addresses specific aspects of research support such as scholarly publication and open access, research performance management and publication support. Leadership, in the form of a Research Support Committee, chaired by the Library's Senior Director, and its Director: Client Services demonstrates the emphasis on developing the Library's research support portfolio. The committee consists of representatives from various divisions such as Research Commons, Information Provision, Digitisation and Digital Services, Branch Libraries and Information Technology. The clustering of these services demonstrates a conceptual approach based on inclusivity whereby research support is regarded as a suite of services with strong collaborative ties rather than a single, uniform structure.

Before engaging in discussion on the role of the Library in the research life cycle (see Figure 1), it is important to discuss the repurposing of Library spaces as it provides the launch pad for the delivery of enhanced research support services. However, this is by no means suggesting that a research commons is an absolute necessity for the delivery of enhanced research support services.

\section{Figure 1 Research life cycle: Stellenbosch University model}



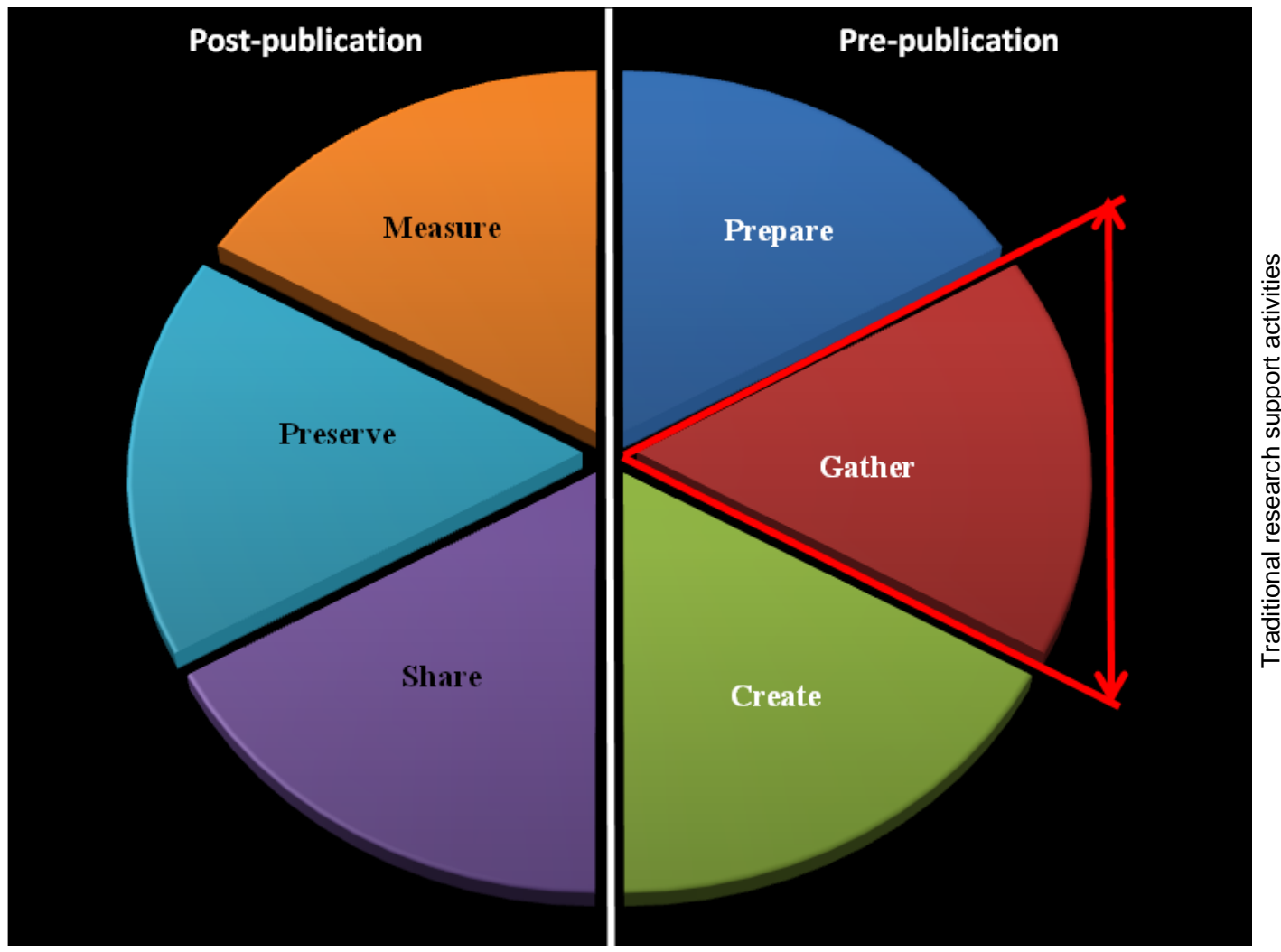

\subsection{Research Commons as a repurposed space}

The creation, growth and development of the Research Commons forms a significant component of the Strategic Directions 2010-2015 (SULIS 2010) of the Library. The purpose of the Research Commons (RC) as stated in the Research Commons: concept document (SULIS 2011) was to create an environment, for postgraduate students and researchers, that engages the principle of collaboration in the delivery of an enhanced service in support of a creative and enriched research process. This purpose is extended to provide research support, in collaboration with partners, to the institution's research and postgraduate communities with the objective of contributing to the increase in:

- through-put of postgraduate students;

- publication of research output via (1) open access forums and/or processes, or (2) traditional publishing model;

- visibility of the Library as a strategic role-player in the research process for local, national and international research output; and

- research and research production culture.

The Research Commons offers a unique blend of collaboration between partners and Library facilities in providing a service to researchers and postgraduate students. It provides a flexible, technology-enabled space for postgraduate students and researchers and supports collaboration between students and academics, and between researchers and research communities. Further, the Research Commons serves as the hub for a range of scholarly activities. The Research Commons co-ordinates the provision of expertise that support the research process (SULIS 2011).

\subsection{Service alignment with the research life cycle}

Given the strategic underpinning of the research commons, the Library is well positioned to provide enhanced research support services. As evident in Figure 1, the Library has gone broader than the traditional research support service. Figure 1 serves as the reference point for the discussion in this section.

\subsubsection{Prepare: scan the research landscape}

The use of research performance management (RPM) tools at Stellenbosch University is not by design. To maximise return on investment for a relatively expensive RPM tool and to justify the expenditure, the Library pursued alternative usage of the Elsevier RPM tool. The Elsevier tool was used to support the researcher to get a more precise view of the research landscape for his/her intended research project. Further, the research librarian assists researchers in identifying experts in the research area. The librarian also assists the researcher, identify funding opportunities related to the potential area of research. Once this service started to gain momentum, it was realised that there were other libraries (internationally) that were using similar products to provide similar services. 
At the point of the development of this paper, the Library had a subscription to SciVal Spotlight, Strata and Experts (Elsevier products) and was actively promoting these tools for the purposes mentioned above. In a presentation at an international conference, Schoombee and Du Plessis (2013) from SU pointed out that SciVal Spotlight was being used to assist "research students to identify research topics based on alignment with institutional research strengths". They also reported a case study demonstrating extensive opportunity provided by SciVal tools to encourage and facilitate research collaboration.

\subsubsection{Gather: information retrieval}

The role of information provider has been, over the years, well-guarded by librarians. However, that monopoly on the dissemination of scholarly literature is showing signs of decay. In response to this decay, librarians at Stellenbosch University are pursuing the role of being a facilitator of improved retrieval of scholarly literature. The role of the librarians is now structured around ensuring that researchers are knowledgeable about available resources, where to find relevant scholarly information, how to use appropriate search strategies, including choosing search terms and search databases, and how to evaluate information. The issue of levels of specialisation, among librarians, is becoming a distinct reality. In the case of Stellenbosch University, the faculty librarian works predominantly with the researcher in the retrieval of information whereas the research librarian and the e-scholarship librarian focus on other aspects of the research life cycle, as indicated in Figure 1.

To strengthen self-retrieval of scholarly literature and to support researchers, the Library is radically expanding its instruction programme for research students and researchers. New workshops are continuously added to address gaps in the research process which existed in previous instruction sessions. In many cases, staff members purposefully engage in self-study to master new topics sufficiently to be able to present workshops. Here, examples include workshops on free reference managing tools, Sage Research Methods Online (SRMO), tools for online storing and sharing of documents, traditional and open access publication strategy and increasing researcher visibility through open access publishing and archiving. Where skills are lacking, they are sourced from external divisions or service providers. Through this strategy, the Library includes sessions on copyright for theses and dissertation students and finding government statistics as part of its portfolio of workshops. To reach off-campus students and researchers in their offices, workshops are increasingly broadcast virtually by means of Big Blue Button and Microsoft Office Live Meeting software.

The use of LibGuides provides a further dimension to instruction efforts, making the content of workshops ubiquitously accessible. Supplementing existing subject-information orientated LibGuides, a number of LibGuides have also been created to address issues pertinent to researchers and postgraduate students. New LibGuides comprehensively address useful resources that correlate with the research process, the scientific publication process, attributes of a good journal, traditional versus open access publication and information about the South African research subsidy system. Other LibGuides suggest research-related tools and applications and promote collaboration facilities, social networks sites and networking software.

The changing of lanes to make researchers more self-sufficient is aligned to the view expressed by Geraghty (2009): what used to be on the fringes of responsibility is now the core and what was at the core is now on the fringe.

\subsubsection{Create: analyse the research results}

As indicated earlier, the Research Commons is viewed as a "one-stop-shop" for the researcher with many of the cognate services coming to the researcher as opposed to the researcher going out to solicit or seek assistance. The Library has a firm commitment to engaging with cognate stakeholders to establish a seamless and enriched service environment for researchers and postgraduate students. To this effect, a grassroots level research support forum provides a platform to share and discuss research service-related topics of mutual interest. Practitioners from the Writing Laboratory, Postgraduate and International Office, Research Development Division, Information Technology and Community Interaction participate in the forum which meets quarterly. Further, the services provided by these practitioners are coopted into the library to assist researchers - it is brought to the researcher, primarily, on demand.

There are various strategies to create awareness of and promote research support services. In particular, the Library hosts a week-long event to showcase its services. The event, Library Research Week, aims to strengthen the perception of the Library as a space where researchers feel nurtured, integrated and connected.

\subsubsection{Share: publish research results}

Given the significance of research production and the need for its widest possible dissemination (as reflected in the Library's strategic plans), the Library has a major role in utilising its repositories to collect, organise and distribute scholarly content. The repository is an authoritative source for all publications of the institution (SULIS 2013).

Scholarly communications and the world of publishing continue to undergo significant changes and development. The Library at Stellenbosch University (SULIS 2010) plays a significant role in promoting a "sustainable model of scholarly communication, assist[ing] in the development and creation of tools and services to facilitate scholarly communication, and recruit[ing] content for the institutional repository". This goal is achieved through:

a) Providing advice and support for open access publishing, including through the Open Journal System (OJS).

b) Enhancing the Institutional Repository (IR) as a facility to showcase the research outputs of the University.

In terms of open access, Stellenbosch University is considered to be a leader on the continent (Raju, Smith and Gibson 2013). Hence, services aligned to open access are well established: however, there is always scope for growth 
and development. The institutional policy that requires mandatory submission of theses and dissertations in electronic format only is testimony to this leadership role. Further, the institution's administration has, in principle, approved the "Policy on mandatory self-archiving of research output" (SULIS 2013). The success of the repository in terms of spearheading open access and increasing researcher visibility was evident in the 2013 Webometrics ranking which placed Stellenbosch University in the top position on the African continent.

Also driving the transformation to openness, is the Library's Open Access Publication Fund which facilitates funding to support and encourage researchers to publish in open access forums. During 2013 this fund subsidised the publication of 102 research articles in accredited, open access journals. An open access system for the electronic management and publication of conference proceedings provides final reinforcement of open initiatives at SU to support and facilitate research dialogue, communication and impact.

The university's leadership role in open access is demonstrated by it being the first African institution to adopt the publication of journals using the open source software, Open Journal Systems. The SUNJournals project, which started in 2010, consolidated in 2012. The number of titles currently hosted by Stellenbosch University has grown to sixteen (SUNScholar 2012).

The success of the SUNJournals project serves as the foundation for the development of the African Open Access Repository Initiative (AOARI). The Library and Information Service of SU launched the AOARI platform (http://ar1.sun.ac.za/) in November 2012. AOARI is a "hyper repository" for African academic and research institutions to share their scholarly literature with the widest possible audience. The primary purpose of the publishing platform is to create a forum to facilitate self-publishing without compromising academic publishing rigour, the preservation of content and the radical improvement in the distribution of scholarly content (Raju, Smith and Gibson 2013: 47).

\subsubsection{Preserve}

The issue of the preservation of research output as a new service is very much in a fledgling stage at Stellenbosch University. The Library does not currently have a long-term preservation policy. It is reliant on the DSpace software which has localised preservation capabilities. Nonetheless, there are practices that ensure duplication through back-up systems and disaster recovery. To ensure continuity in the event of disasters, there is a UNIX back-up to two identical servers distributed between the Library and the University's central Information Technology department. A third back-up is a tape format to the University's disaster recovery room which is located underground off-campus.

Despite the lack of a preservation policy, the authors acknowledge that there has been significant planning to ensure long-term preservation. For example, research articles that are submitted to a repository must comply with certain file formats that allow for continued accessibility. The objective is to preserve material by converting it into a digital object format in such a way that the digital objects created may be read and understood by future technology systems. File formats such as pdf/a, open documents and media codec (coder decoder) facilitate long-term preservation. Further, material submitted to the repository use open published digital format standards (Raju et al. 2012: 7).

There is substantial scope for the development of the research support service relating to the preservation of the research output at Stellenbosch University.

\subsubsection{Measure}

Again, the aspect of measurement and impact as a service offered by the Library is on a steep learning curve. Currently, research impact measurement is supported in a very limited way. Researchers are assisted with using metrics to support decision-making about where to publish. Faculty librarians also assist with queries related to $h$-index, journal impact factor and journal citation reports. Limited support is provided for altmetrics (tools measuring research impact in social and open access forums and platforms), focusing mainly on Google Scholar metrics and Google Scholar citations. A LibGuide with extensive information about bibliometric tools and resources is available to support researchers in the effective use of tools to determine and increase their research impact.

As with preservation, substantial inroads have to be made to offer "measure" as a fully-fledged service to the research communities of Stellenbosch University.

\subsection{Limitations of Stellenbosch University practice}

Notwithstanding that research support librarianship globally is still in its infancy, there are clear shortcomings to the services provided by Stellenbosch University despite its distinct leadership on the African continent. There are aspects of research support that need urgent attention, over and above those mentioned. Some of these aspects include having a comprehensive research support charter; having a clear, concise and differentiated service model to optimise expertise in publication matters and bibliometrics; having a clear definition for (or framework for demarcating) research support; and resolving the differentiation between the needs of different categories of researchers and postgraduates. Attention must also be given to improving researcher visibility, researcher profiling and unique author identification. It is evident that data management and curation services are seriously lagging as compared to international practice. As much as there have been discussions on research data management, given other priorities such as open access, little has been done in terms of research data management. 


\section{Conclusion}

The shift from being on "life support" to a significant contributor to research production has and will continue to have a profound influence on the way academic libraries conduct business. In this transformation, libraries have found their deeper meaning for researchers through the expansion of their suite of research support services. The change in currency for research from information to data has also influenced the academic library's transition. The repurposing of library spaces as a direct response to the exponential growth of information and data in digital format has also contributed to the transformation of academic libraries and which has served as the launch pad for new services such as research data management, open access, data curation and bibliometric analysis.

The identification of international trends in this paper served as a yardstick to measure the disparity in the scope and depth of research support services between international institutions and Stellenbosch University. It is accepted that the paper does not (and could not) measure the depth of services offered; however, there is sufficient evidence to show that Stellenbosch University, one of the leading academic institutions on the continent, does receive significant research support from its library. The Library, from pre-publication to post-publication, offers research support services that contribute to the leadership status of the university - leadership in finding solutions to Africa's challenges in critical areas of development.

It is acknowledged that the Stellenbosch University Library and Information Service does not offer the same depth and breadth of research support as its counterparts in other countries such as Australia and the United Kingdom. Therefore, as a leader on the continent, it is imperative that the Library continues to push boundaries. Other higher education institutions in South Africa need to collaborate to ensure that the challenge is taken up by all academic librarians to make this shift. More importantly, library leadership (that is, directors and executive directors) must be bold and invest in resources that would add value to institutional and national imperatives that would benefit from research support services and their concomitant influence on research production and the dissemination of that production. The LIS professional association in South Africa (Library and Information Association of South Africa) needs to play a more active role in mediating between the libraries and their librarians and LIS schools to ensure that the competency levels of librarians are adequate to engage in this transformation. LIS schools need to be flexible enough to design their curricula to ensure that they are training librarians for contemporary library and information practices.

Research support services are an imperative in the current digital age and all stakeholders need to collaborate to ensure its successful application. Africa's transition from the periphery of research production to the epicentre is dependent on quality research output. Libraries have a significant role to play in the quest for an acceleration of quality research output.

\section{References}

Al, U., Soydal, I. and Alı'r, G. 2012. Trends in research librarianship literature: a social network analysis of articles. Liber quarterly, 21(3/4): 429-444. Available: http://www.bby.hacettepe.edu.tr/yayinlar/dosyalar/article-liber.pdf (01 September 2013).

Anderson, R. 2011. The crisis in research librarianship. The journal of academic librarianship, 37(4): 289-290. Available: http://content.lib.utah.edu/cdm/ref/collection/uspace/id/1467\#img_view_container (01 September 2013).

Association of Research Libraries. 2010. ARL 2030 scenarios: a user's guide for research libraries. Association of Research Libraries, Washington, DC. [Online]. http://www.arl.org/focus-areas/planning-visioning/scenarioplanning/1074-the-arl-2030-scenarios-a-users-guide-for-research-libraries (20 November 2013).

Astrom, F., Hansson, J. and Olsson, M. 2011. Bibliometrics and the changing role of the university libraries. [Online]. http://www.academia.edu/1136574/Bibliometrics_and_the_Changing_Role_of_the_University_Libraries (25 November 2013).

Basefsky, S.M. 2009. The end of institutional repositories and the beginning of social academic research service: an enhanced role for libraries. [Online]. http://works.bepress.com/stuart_basefsky/4 (01 September 2013).

Bennett, S. 2008. The information or the learning commons: which will we have? The journal of academic librarianship, 34(3):183-185.

Borgman, C.L. 2010. Research data: who will share what, with whom, when, and why? Fifth China-North American Library Conference, Beijing, 8-12 September. Available: http://sydney.edu.au/research/data_policy/resources/ANDS_Borgman_2010_research_data.pdf (01 September 2013).

Bradbury, K. and Weightman, A. 2010. Research support at Cardiff University Library. SCONUL focus, 50: 65-70. Available: http://www.sconul.ac.uk/sites/default/files/documents/19_2.pdf (11 November 2013).

Charbonneau, D.H. 2013. Strategies for data management engagement. Medical reference services quarterly, 32(3): 365-374. Available: http://dx.doi.org/10.1080/02763869.2013.807089 (01 September 2013).

Corrall, S., Kennan, M.A. and Afzal, W. 2013. Bibliometrics and research data management services: emerging trends in library support for research. Library trends, 61(3): 636-674.

Denscombe, M. 2012. The good research guide. $4^{\text {th }}$ ed. Open University Press: Berkshire.

Drummond, R. and Wartho, R. 2009. RIMS: the research impact measurement service at the University of New South Wales. Australian academic and research libraries, 40(2): 76-87. Available: http://www.tandfonline.com/doi/pdf/10.1080/00048623.2009.10721387 (21 October 2013). 
Fouché, C.B. and Delport, C.S.L. 2012. In-depth review of literature. In Research at grass roots: for the social sciences and human service professions. $4^{\text {th }}$ ed. A.S. de Vos, H. Strydom, C.B. Fouche and C.S.L. Delport, Eds. Van Schaik: Cape Town. 133-141.

Gayton, J.T. 2008. Academic libraries: "social" or "communal?": the nature and future of academic libraries. The journal of academic librarianship, 34(1): 60-66. Available: http://www.sconul.ac.uk/page/libraries-of-the-future-scenarios-for2050 (28 August 2008).

Geraghty, A. 2009. The role of the research support librarian. ANLTC (Academic and National Library Training CoOperative): meeting the information needs of researchers. National University of Ireland, Galway, June 2009. [Online]. http://www.eahil.eu/conferences/2009Dublin/www.eahil2009.ie/images/Eahil/lmages/papers/fri7/eustace.pdf (21 October 2013).

Gorman, G.E. and Clayton, P. 2005. Qualitative research for the information professional: a practical handbook. London: Facet.

Jisc. 2013. Increase the visibility and impact of your research. [Online]. http://www.jisc.ac.uk/guides/increase-the-visibilityand-impact-of-your-research (01 December 2013).

Kwanya, T., Stilwell, C. and Underwood, P.G. 2012. A competency index for research librarians in Kenya. African journal of library, archives and information science, 22(1):1-18.

Lapinski, S., Piwowar, H. and Priem, J. 2013. Riding the crest of the altmetrics wave: how librarians can help prepare faculty for the next generation of research impact metrics. College and research libraries news, 74(6): 292-300. Available: http://crln.acrl.org/content/74/6/292.full.pdf+html (10 January 2013).

Leedy, P.D. and Ormrod, J.E. 2013. Practical research: planning and design. $10^{\text {th }}$ ed. Pearson: Cape Town.

Lee-Hwa, T., Abrizah, A. and Noorhidawati, A. 2012. Availability and visibility of open access digital repositories in ASEAN countries. Information development, 29(3): 275-285.

Lynch, C. and Carleton, D. 2009. The impact of digital scholarship on research libraries. The journal of library administration, 49(3): 227-244

MacColl, J. and Jubb, M. 2011. Supporting research: environments, administration and libraries. Dublin, Ohio: OCLC Online Computer Library Center. [Online]. http://creativecommons.org/licenses/by-nc-sa/3.0/ (11 November 2013).

Park, J-H. and Shim, J. 2011. Exploring how library publishing services facilitate scholarly communication. Journal of scholarly publishing, 43(1): 76-89. Available: http://muse.jhu.edu/journals/journal_of_scholarly_publishing/summary/v043/43.1.park.html (21 October 2013).

Parker, R. 2012. What the library did next: strengthening our visibility in research support. emPowering efutures. VALA $201216^{\text {th }}$ Biennial Conference, Melbourne, Australia, 6-9 February. [Online]. http://www.vala.org.au/vala2012proceedings (18 January 2013).

Pennington, T.M. 2012. Third space: creating a library environment that opens doors for collaboration, value, and student achievement. [Online]. http://centralspace.ucmo.edu/xmlui/bitstream/handle/10768/119/TPennington_LIBRARYSCIENCE.pdf?sequence=1 (18 January 2013).

Raju, R. and Schoombee, L. 2013. Research support in a 21st century academic library: a case study of Stellenbosch University Library and Information Service. SARIMA conference: Promoting research excellence, relevance and impact: the research and innovation manager's role. College of Medicine of South Africa, Cape Town, 8 - 9 July 2013.

Raju, R., Smith, I. and Gibson, H. 2013. Opening access to African scholarly content: Stellenbosch University's AOARI platforms, Insights, 26(1): 44-50.

Raju, R., Smith, I., Gibson, H. and Talliard, P. 2012. Open access: are we there yet? The case of Stellenbosch University, South Africa. South African journal of libraries and information science (Special open access launch issue). Available: http://sajlis.journals.ac.za/pub/article/view/29/29 (10 January 2013).

Richardson, J., Nolan-Brown, T., Loria, P. and Bradbury, S. 2012. Library research support in Queensland: a survey. Australian academic and research libraries, 43(4): 258-277. Available: https://eprints.usq.edu.au/23002/ (21 October 2013).

Riera-Quintero, C., Padrós-Cuxart, R. and Zuñiga-Ruiz, A. 2012. Research librarians in a virtual environment: new skills, new services. [Online]. http://openaccess.uoc.edu/webapps/o2/handle/10609/15321 (07 June 2013).

Roemer, R. C. and Borchardt, R. 2012. From bibliometrics to altmetrics: a changing scholarly landscape. College and research libraries news, 73(10): 596-600. Available: http://crln.acrl.org/content/73/10/596.full.pdf+html (22 October 2013).

Schoombee, L. and Du Plessis, P. 2013. Making the link: the library's role in facilitating research collaboration. $34^{\text {th }}$ Annual IATUL Conference. Cape Town, South Africa. April 2013. [Online]. http://docs.lib.purdue.edu/cgi/viewcontent.cgi?article=1952\&context=iatul (03 August 2013).

SCONUL (Society of College, National and University Libraries). 2011. Libraries of the future: scenarios for 2050. [Online]. http://www.sconul.ac.uk/page/libraries-of-the-future (11 November 2013).

Sennyey, P., Ross, L. and Mills, C. 2009. Exploring the future of academic libraries: a definitional approach. Journal of academic librarianship, 35(3): 252-259. Available: http://www.sciencedirect.com/science/journal/00991333 (20 February 2011).

Staley, D.J. and Malenfant, K.J. 2010. Futures thinking for academic librarians: higher education in 2025. Information services and use, 30: 57-90. 
Stoffle, C.J. and Cuillier, C. 2011. From surviving to thriving. Journal of library administration, 51:130-155. Available: http://www.tandfonline.com/doi/abs/10.1080/01930826.2011.531645 (10 July 2013).

Stoffle, C.J., Leeder, K. and Sykes-Casavant, G. 2008. Bridging the gap: wherever you are, the library. Journal of library administration, 48(1): 3-30. Available: http://jla.haworthpress.com (05 August 2013).

SULIS (Stellenbosch University Library and Information Service). 2010. Strategic Directions 2010-2015. Unpublished strategy document: Stellenbosch University.

SULIS (Stellenbosch University Library and Information Service). 2011. Research Commons: concept document. Unpublished concept document: Stellenbosch University.

SULIS (Stellenbosch University Library and Information Service). 2013. Policy on mandatory self-archiving of research output. Unpublished policy document: Stellenbosch University.

SUNScholar. 2012. The African Open Access Repository Initiative. [Online]. http://ar1.sun.ac.za/ (20 November 2013).

Surprenant, T.T. and Perry, C.A. 2002. The academic cybrarian in 2012: a futuristic essay. [Online]. http://www.google.co.za/search?hl=en\&rlz=1T4SKPB_enZA289ZA289\&q=surprenant+perry+cybrarian\&meta (08 October 2012).

Tenopir, C., Birch, B. and Allard, S. 2012. Academic libraries and research data services: current practices and plans for the future. Association of College and Research Libraries. [Online]. http://www.ala.org/acrl/sites/ala.org.acrl/files/content/publications/whitepapers/Tenopir_Birch_Allard.pdf (25 November 2013).

Tenopir, C., Sandusky, R.J., Allard, S. and Birch, B. 2013. Academic librarians and research data services: preparation and attitudes. IFLA journal, 39. [Online]. http://ifl.sagepub.com/content/39/1/70 (25 November 2013).

Thachill, G. 2008. Academic libraries redefined: old mission with a new face. SCROLL: essays on the design of electronic texts, 1(1). [Online]. http://fdt.library.utoronto.ca/index.php/fdt/article/view/4913/1780 (05 November 2013).

UNESCO. 2009. World Conference on Higher Education: the new dynamics of higher education and research for societal change and development. UNESCO, Paris, 5-8 July 2009. [Online]. http://www.unesco.org/fileadmin/MULTIMEDIA/HQ/ED/ED/pdf/WCHE_2009/FINAL\%20COMMUNIQUE\%20WCHE\% 202009.pdf (25 June 2011).

Walker, C.M. 2009. Emerging challenges for Carnegie Research Librarians at Wits. [Online]. www.gaelic.ac.za/docs/camp-walkercarnegiechallenges.pdf (25 June 2011). 